\title{
Analysis and Modeling the Streambed Evolution after the Check Dam Restoration: the Case of Krzczonówka Stream
}

\author{
Marta Łapuszek ${ }^{1}$ \\ 1 Institute of Water Engineering and Water Management, Cracow University of Technology, ul. Warszawska 24, \\ 31-155 Kraków, Poland, e-mail: mlapusze@iigw.pl
}

\begin{abstract}
In the Upper Vistula Basin, series of check dams are located on almost each of mountain stream. These streams are strongly affected by the presence of dams that disrupt the sediment movement in the channel. Moreover, the check dams are in poor technical condition. The current study focuses on the Krzczonówka Stream, a left-bank tributary of the Raba River, where restoration works were undertaken in 2014 involving lowering of a check dam. The aim of the project was the continuity of the stream corridor for fish migration restoration. This paper aims to provide an analysis of the streambed evolution and a numerical analysis of the impact of check dam lowering and removal of sediment, previously accumulated upstream under the geomorphologic conditions in the studied stream after three years of project execution. A 1D sediment transport model was employed to estimate the areas of erosion and deposition throughout the river course. The calculations show that the thickness of the deposited sediment ranged from 0.20 up to $0.91 \mathrm{~m}$ at $1.5 \mathrm{~km}$ of the reach. The layer thickness deposited form 2.1 to $1.75 \mathrm{~km}$ of the reach, is rather thin; subsequently, the layer thickness increases and the highest values are reached at the area of $1.35-1.7 \mathrm{~km}$. The local erosion is observed in $1.1 \mathrm{~km}$ of the reach. It is very important to note that the identified erosional and accumulation tendencies are the same at corresponding cross sections measured as calculated based on the model. This also provides a practical form of model validation. Additionally, the stream channel evolution on the base on low annual water stages in Krzczonów gauging station, located downstream the dam, indicates that the bottom has increased in this section by about $50 \mathrm{~cm}$. The comparison of cross-sectional geometry in years of 2015-2016 (after flood event) shows that the stream channel moved in the transverse direction (bank erosion and deposition) and the streambed level has changed slightly. Currently, the stream channel does not seem to be in a state of hydrodynamic equilibrium. Thus, further field measurements will try to indicate when this balance is achieved.
\end{abstract}

Keywords: check dam, sediment movement, river restoration.

\section{INTRODUCTION}

A check dam is a hydraulic structure, which is constructed in order to limit the river sediment transport. A sedimentation reservoir is created upstream from the dam wall, where river sediment is constantly accumulated. Check dams were constructed starting in the early $20^{\text {th }}$ century in the upstream parts of mountain rivers in the Polish part of the Carpathian Mountains (Hubicki, 1927). Their main purpose was to trap the river sediment transported downstream. The largest number of check dams in Poland is found in the Raba and Dunajec catchments in the Carpathian Mountains in the southern part of the country.
All of these structures were designed to serve as the river engineer's answer to an excessive transport and accumulation pattern of sediment in Carpathian stream channels. The streams carried both their own sediment produced due to downward cutting and lateral cutting in the streambed as well as the sediment supplied in huge amounts by local catchments, the hillslopes of which were used for agriculture at the time (Kaszowski et al., 1977). At present, the reservoirs of most check dams are already fully filled with sediment (Ratomski 1991), and the impact of these structures on the ecosystems of streams is unfavorable (Klimek 1972, Korpak 2007). Moreover, dams that have not been renovated are in poor technical 
condition and are structurally damaged near the core area of the dam or spillway. Therefore, any further operation of these check dams in Carpathian stream channels in their present technical condition becomes a problem, especially since while interrupting the flow in a stream channel, they constitute a transverse barrier to the migration of aquatic organisms. Thus, the damaged check dams cause a permanent interruption in the continuity of the ecological corridor of streams in the Carpathians and elsewhere (Korpak et al., 2008).

There are some ideas of changing their constructions in order to restore the hydromorphological conditions in the stream channel and enable the fish migration (EFD - 23 October 2000). The aims of river hydromorphology restoration projects may include facilitating sediment transport, restoring continuity for any aquatic species, and re-establishing waterway connections (Jeleński et. al., 2016).

Restoration works have been performed in recent years in the channels of the Krzczonów$\mathrm{ka}$, the Carpathian stream that is a tributary of the Raba River. The restoration works involved both the lowering and remodeling of check dams. The project was called "The Upper Raba River Spawning Grounds" and organized by the Ab Ovo Association (http://tarliskagornejraby.pl/). Its primary aim was to restore the continuity of the river corridor for the Salmonidae family fish migration. The restoration work on the Krzczonówka stream was performed in the years 2013-2014, which involved lowering of a check dam. Another project concerning migration barriers as steps and mill-dams removal was carried out in the Wisłoka River catchment area (Sobieszczyk 2017).

This paper aims to present the analysis of river channel processes with regard to the determination of the direction of channel evolution and the time required to achieve the hydrodynamic balance, as well as the numerical analysis of the impact of the check dam lowering process and the removal of the sediment previously accumulated upstream under the geomorphologic conditions in the stream. It is also important to show that the applied model may be useful (validation) to forecast the river channel changes in a mountain river.

\section{THE STUDY AREA}

The Krzczonówka Stream, a tributary of the Raba River, drains a $92.2 \mathrm{~km}^{2}$ catchment in the southern region of Poland (Figure 1). In 1879, the Krzczonówka river channel was wide and alluvial along the entire researched, downstream reach. The construction of a check dam was started in 1935 at kilometer $2+440$ of river course. The hydraulic structure was made of concrete with a stone front, and the height of the dam was approximately $7 \mathrm{~m}$ (Project No. 46/43/1473). The check dam had interrupted the natural continuity of the fluvial system, thus limiting the supply of sediment from the upstream section of the river. The average width, in the reach downstream from the check dam, decreased from $41 \mathrm{~m}$ to $24 \mathrm{~m}$, and the average width in the reach upstream from the dam decreased from $105 \mathrm{~m}$ to $23 \mathrm{~m}$ (Lenar-Matyas et al., 2015). At present, the stream channel width within the entire 5-kilometer long reach of the channel is about the same and very small. Preliminary work on the lowering of an existing check dam on the Krzczonówka Stream was begun in 2013. Finally, in 2014, the check dam on the Krzczonówka Stream was lowered, redesigned, and rebuilt as a cascade (Photo 1b). Downstream
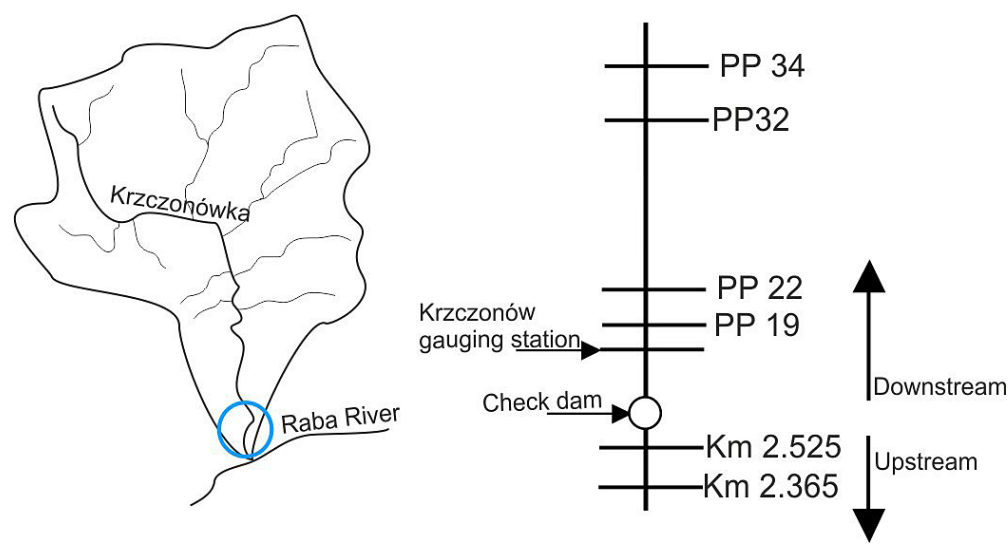

Figure 1. The Krzczonówka catchment and scheme of studied stream course with pointed out: the check dam, the Krzczonówka gauging station, analyzed in Figure 4 cross-sections 


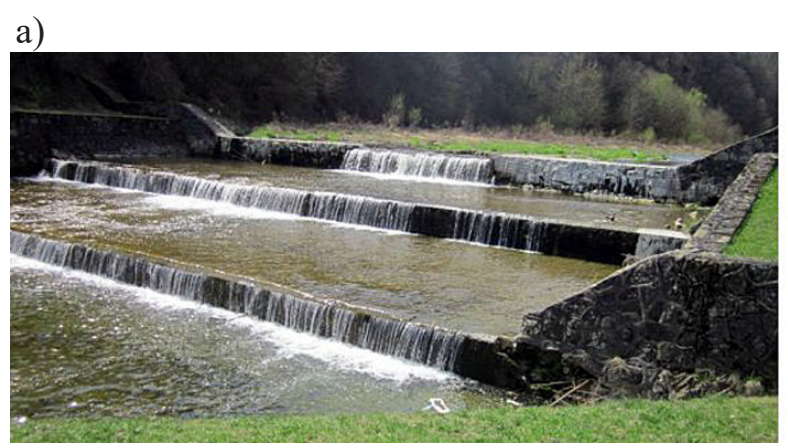

b)

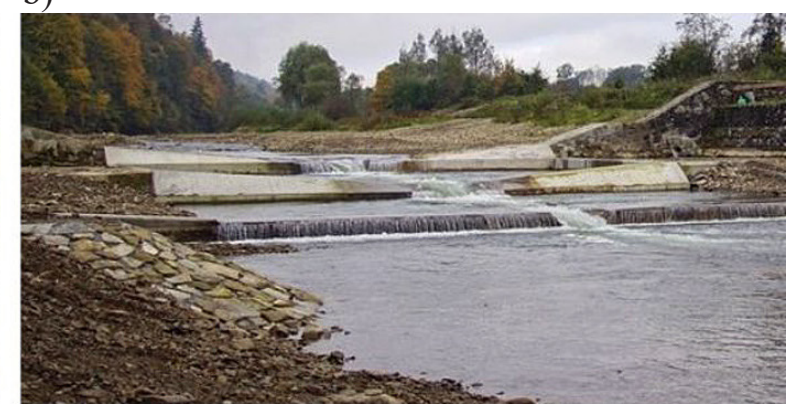

Photo 1. Check dam on the Krzczonówka stream: a) before restoration (Photo: M. Lapuszek, May 2013), b) after restoration (Photo: tarliskagornejraby.pl)

from the modified dam, nine man-made riffles were constructed in the stream channel, the purpose of which was to reduce the excessive, downward slope of the stream bed.

\section{MATERIALS AND METHODS}

Monitoring of the "Tarliska Górna Raba" project area is carried out by the team of the Institute of Water Engineering and Water Management. The monitoring includes the thalweg of the river channel surveying for a reach $0.610 \mathrm{~km}-3.600 \mathrm{~km}$ using a GPS Topcon Hiper II to document the river channel topography. Surveys were completed once before the check dam lowering in 2013 and three times after dam lowering: in 2014, 2015 and 2016.

On the basis of the above-mentioned field observations and measurements, the analysis of river channel evolution was conducted as follows:

Daily water discharges were analyzed (according to Poland's Institute of Meteorology and Water Management) in Krzczonowka gauging station in the year of 2014. Then, the stream power was calculated to infer the erosional capacity of the flood event (Bagnold, 1966):

$$
\omega=\rho g Q S \text {. }
$$

where: $\omega$ is the maximum stream power, $\rho\left(\mathrm{kg} \cdot \mathrm{m}^{-3}\right)$ is the fluid density,

$g\left(\mathrm{~m} \cdot \mathrm{s}^{-2}\right)$ is the acceleration because of gravity,

$Q\left(\mathrm{~m}^{3} \cdot \mathrm{s}^{-1}\right)$ is discharge,

$S$ is the channel slope.

The numerical analysis of the impact of the check dam lowering process and the removal of sediment previously accumulated upstream under the geomorphologic conditions in the stream was carried out. A one-dimensional model (Łapuszek et al., 2007) was used. The model involves the Saint Venant equations for water, equation for sediment mass conservation (Paquier 2003) and sediment transport capacity relation (Meyer-Peter and Müller, 1948).

Analysis of river channel evolution in Krzczonówka gauging station was performed on the basis of assumption that minimal annual water stages correspond to the changes of the riverbed level (Łapuszek 2013).

The net amount of river channel erosion or deposition amount between surveys was determined. The rates of change in area at each cross section for the water level of $\mathrm{Q}_{50 \%}$ surveyed from 2013 to 2016 were calculated periodically.

\section{RESULTS AND DISCUSSION}

Daily discharge at the Krzczonów gauging station in 2014 year is provided in Fig. 2a). Before the check dam lowering and restoring, the highest discharge was $8.47 \mathrm{~m}^{3} \mathrm{~s}^{-1}$ (according to Poland's Institute of Meteorology and Water Management). Only a single flood event occurred after the dam restoration. Figure 2 illustrates the hydrograph of that event. The maximum recorded discharge was $164 \mathrm{~m}^{3} \mathrm{~s}^{-1}$ (according to Poland's Institute of Meteorology and Water Management). The subsequent discharges in 2015 and 2016 were lower than $23 \mathrm{~m}^{3} \mathrm{~s}^{-1}$. The maximum stream power of the Krzczonówka stream at the gauging station and at the cross-sections as located in the Figure 1 (PP19, PP22, PP32, PP34) were estimated to be $59076,96,78833,18437 \mathrm{~kg} \cdot \mathrm{m} / \mathrm{s}^{3}$, respectively during the flood.

The stream channel responses were greatest immediately after check dam lowering due to the flood. 


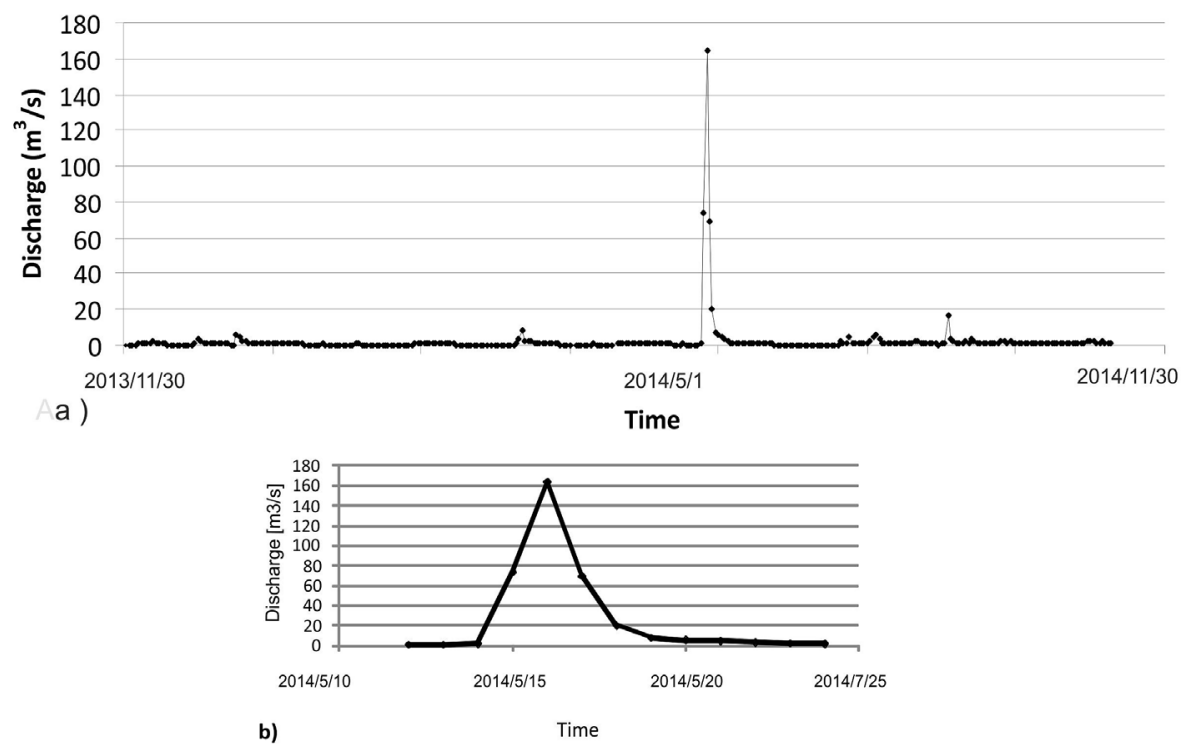

Figure 2. a) Hydrograph of The Krzczonówka stream registered at Krzczonów gauging station for 2014; b) Recorded daily discharge of the flood event at Krzczonów gauging station (according to Poland's Institute of Meteorology and Water Management)

The field measurements carried out in the channel of Krzczonówka Stream after a flood revealed that great changes had occurred in the stream channel. The number of mid-channel bars significantly increased in the reach downstream from the check dam. The size of side bars and mid-channel bars had also increased. Some stream channel reaches became covered with a thick layer of sediment (Figure 4a,b,d). At the same time, the number of erosion-produced side cuts increased, while the number of knickpoints and rock outcrops decreased (Fig. 4c). Deposition is currently the primary process shaping the stream channel downstream the dam. This occurred due to the vast amount of sediment entrained during the flood event (Fig. 2b). The sediment load that was to be transported by the stream exceeded its carrying capacity. The material was supplied from the upstream section of the channel, which lies upstream of the check dam (as a result of its lowering) and from the side cuts due to lateral erosion of the banks (Figure 4e,f). In some channel reaches, the bank was moved back several tens of centimeters, while some bank reinforcements became substantially damaged. The structure of most new riffles was not visible. A small bump in the down slope of the channel is found where the riffles used to be.

On the basis of the obtained results, it may be stated that the stream channel, within long sections of it, was filled with the material released from the sedimentation reservoir of the dam (Figure 4e,f), and also with additional material from the right bank, where strong lateral erosion had occurred.

Strong erosion, due to a flood event, in the stream channel section located upstream of the check dam was observed. The material deposited

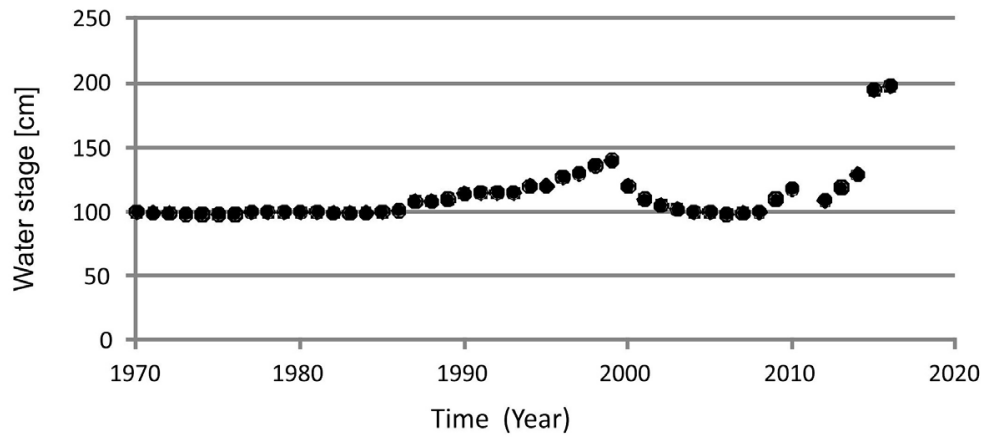

Figure 3. Lowest annual water stages at the Krzczonów gauging station in years: 1970-2016 (according to Poland's Institute of Meteorology and Water Management) 

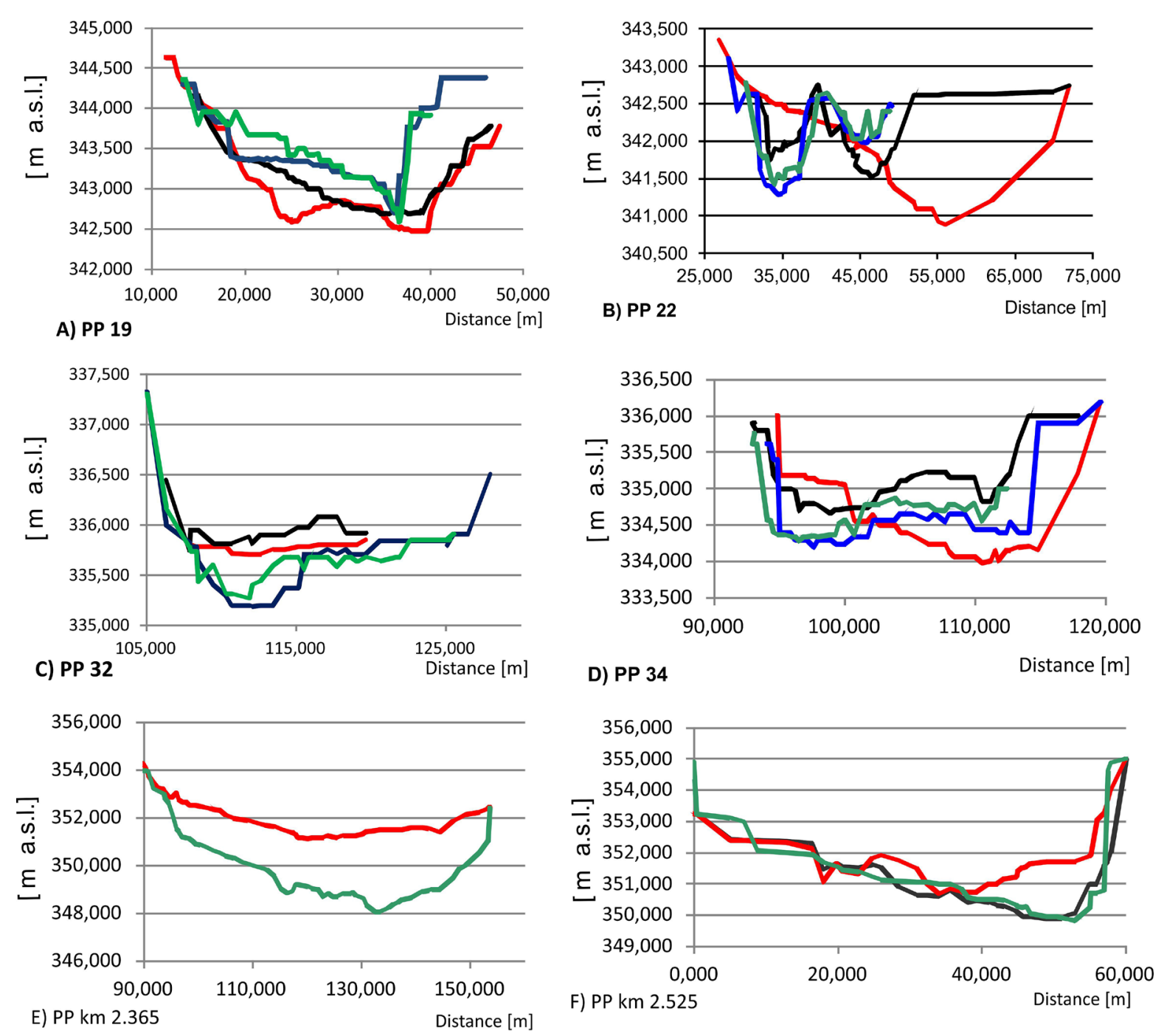

Figure 4. Representative cross-sectional elevation changes over time on Krzczonówka Stream downstream the lowered check dam (a-d) and upstream the dam (e-f), red line: 2013, black: line 2014, blue line: 2015, green line: 2016 year

up to that time within the dam reservoir and above it, became eroded and transported to the channel reach downstream of the dam (Fig. 4e,f).

The increased discharge caused an entrainment of the material deposited in the sedimentation reservoir of the check dam. The material, set in motion, was transported down the stream, which caused certain changes, including the fact that the streambed level was raised at the gauging station. It was noticed in the values of lowest annual water stages established for 2015 and 2016 (Fig. 3). The values of lowest annual water stages are about $50 \mathrm{~cm}$ higher than those recorded in the previous years. This indicates that the bottom in this section has increased by about $50 \mathrm{~cm}$.

The field measurements of cross-sections geometry taken in September 2015 and September
2016 show no significant effects on the change in the channel geometry. The subsequent discharges in 2015 and 2016 were lower than $23 \mathrm{~m}^{3} \mathrm{~s}^{-1}$. The maximum stream power of the Krzczonówka stream at the gauging station and at the cross-sections, as located in the Figure 1, were estimated to be $8285,13,11055,2585 \mathrm{~kg} \cdot \mathrm{m} / \mathrm{s}^{3}$ respectively for lower discharge. Therefore, in 2015, the changes of the channel geometry were visible, but not high. In 2016, the changes were very slight comparing to 2015 (Fig. 4a,d).

It may be asserted that the sediment deposited in the year 2014 was successively being transported down the stream. The measurements and inspections in the field indicate that the sandbars created during the last major flood event have become partially reinforced with vegetation. The 
stream channel reach upstream from the dam may also be considered stable; intense channel processes are not observed there. Erosion, which occurred due to the draining of the reservoir, did not intensify. The stream channel remained at the same level, and the bars at low flow rates are gradually being reinforced with vegetation. Thus, sediment is not supplied to the river channel downstream of the debris field at the present time.

Analyzing the changes in the cross-sectional area at the level of $\mathrm{Q}_{50 \%}$, in years 2013-2016, it can be clearly noticed that the cross-sectional areas drastically decreased in 2013-2014 over the whole section below the check dam (Fig. 5). In subsequent years, the cross-sectional areas were increased due to the sediment movement, especially in the km 1.475-0.995. Along a subsequent reach of the stream channel, the cross-sectional area keeps decreasing within the range from $47 \%$ to $2.54 \%$, which is the minimum value that occurs at cross section 34 (Fig. 5)

A one-dimensional model (Lapuszek et al., 2007) was used to estimate the impact of check dam lowering and removal of the sediment previously accumulated upstream under the geomorphologic conditions in the river channel. Numerical, one-dimensional models are commonly used for the analysis of many morphologic processes (Krishnappan, 1981). For instance, 1D models are used for the simulation of degradation of alluvial channel beds below a dam (Krishnappan, 1981, Park et al., 1987) and for the simulation of riverbed evolution for bed-load sediment mixtures (Rahuel et al., 1989). The sediment transport mostly occurs during high flows. Thus, flood events should be modeled in a detailed way in order to assess the main morphologic changes.

The case of emptying the reservoir of sediment and its movement down the Krzczonówka
Stream occurred during an extreme flood in 2014. This fact implies that unsteady flow modeling should be necessary. Thus, the coupling of sediment transport modeling and flow modeling is appropriate. In mountain rivers, flood events only last a short period of time and stream bottom evolution is rather fast. This point can cause some difficulties for the calibration of a sediment transport model that generally only relies on the measurements performed before and after the flood event. However, if the measurement of the channel geometry was performed shortly after the flood event, the result provided should be a reliable one for model calibration. The processes inside the river itself could then be followed using both small space and time intervals. Nevertheless, except for answering questions concerning hydraulic structure, the main questions remain at the scale of the whole reach of a river, for which the river flow can be described by a 1-D model. This implies that in most cases, a 1-D sediment transport model is the more relevant model, because it takes into account a smaller number of parameters, which also means a simpler calibration process. The key difficulty in model calibration, and therefore in adjusting it to calculate the transfer of sediment during the flood event that occurred at the time of dam lowering, occurred due to the lack of archived gauging data for the Krzczonówka channel reach downstream from the dam. Regularly performed cross sections of the channel and the valley, measured in the field, date back to the spring of 2013 or before the lowering of the dam. These were used to develop the model - a total of 16 cross sections. The remaining cross sections were obtained through the use of interpolation with a step of $50 \mathrm{~m}$, with a maximum step of $100 \mathrm{~m}$, for the purpose of performing calculations. It was possible to obtain daily

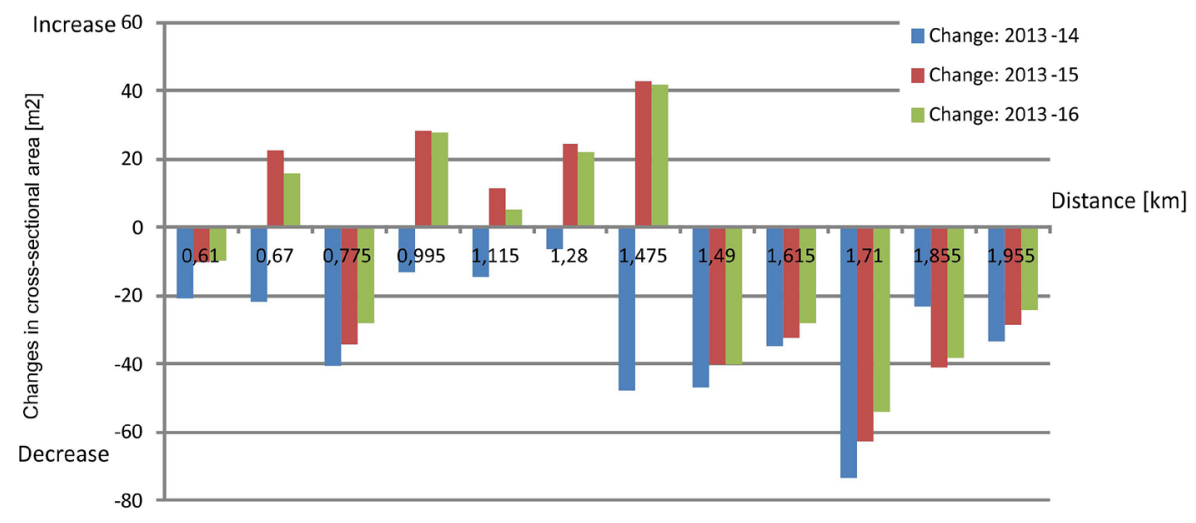

Figure 5. Changes in cross-sectional area in years 2013-2016 
water level readings using the stream gauge in the Krzczonówka channel, which was located at $1.940 \mathrm{~km}$ of the channel reach for which the calculations were performed. Therefore, it was possible to select a sequence of discharge values which had an influence on the shaping of the channel, or in other words, the discharge values that may have triggered the transport of sediment. It was checked if the morphology of the riverbed after the above-mentioned sequence of discharge values was similar to the measured in the field in 2013. The Strickler coefficient, the porosity and the active width were calibrated.

A simulation was performed for the stream channel section, found downstream from the dam being lowered, and for the propagation of the flood wave of peak discharge, assuming that the sediment mass was moving from the already lowered dam further down the stream channel.

Looking at the longitudinal profile of the studied stream channel (Fig. 6), it can be noticed that the stream bed elevation has increased along the entire reach. The thickness of deposited sediment ranged from 0.20 up to $0.91 \mathrm{~m}$ at $1.5 \mathrm{~km}$ of the reach. The layer thickness deposited form 2.1 to $1.75 \mathrm{~km}$ of the reach, is rather thin; subsequently, the layer thickness increases and the highest values are reached at the area of 1.35-1.7 $\mathrm{km}$ (Fig. 4: PP22). The local erosion is observed in $1.1 \mathrm{~km}$ of the reach (Fig. 6).

The process of intensive erosion on the area located directly below the check dam ( $\mathrm{km}$ from 2.2 to 2.0 ) is observed (Fig.6). This process observed just after the check dam lowering is difficult to interpret. This area is directly affected by the works related to the reconstruction of the check dam. It will be possible to assess the processes occurring there in the subsequent years of observation.

The water level throughout the analyzed stream reach is varied. The several riffles can impact it. The largest increase in the water level with respect to the level prior to the studied flood event, can be observed between 1.68 and 1.15, immediately downstream from riffle no. 4. This situation can be explained by the fact that a high side bar had formed on the right bank of the studied stream channel, which substantially decreased the capacity of the river channel to carry water. The sediment was deposited at the site in large quantities most likely due to the simultaneous occurrence of the following factors: (1) decrease in the longitudinal slope of the channel; (2) loss of flow velocity across the riffle, which led to a decrease in the carrying capacity of the water flow and (3) active layer width and the main river channel width in the case of very irregular cross-section profile are different and can lead to differences in the volumes of computational and measured sediment transport. The maximum thickness of the sediment deposited at this site is $90 \mathrm{~cm}$, using the channel bottom elevation measured prior to the flood event as the reference level. A similar situation occurred near riffle no. 2 (km 1.15). However, in this case, the main cause for the formation of the bar was a pillar supporting a footbridge, which caused a "shadow" effect and accumulation of transported material in the form of a scarp downstream from the pillar.

The calculation results summarizing the lowest value of riverbed elevation, both those measured in 2014 and the values based on model cal-

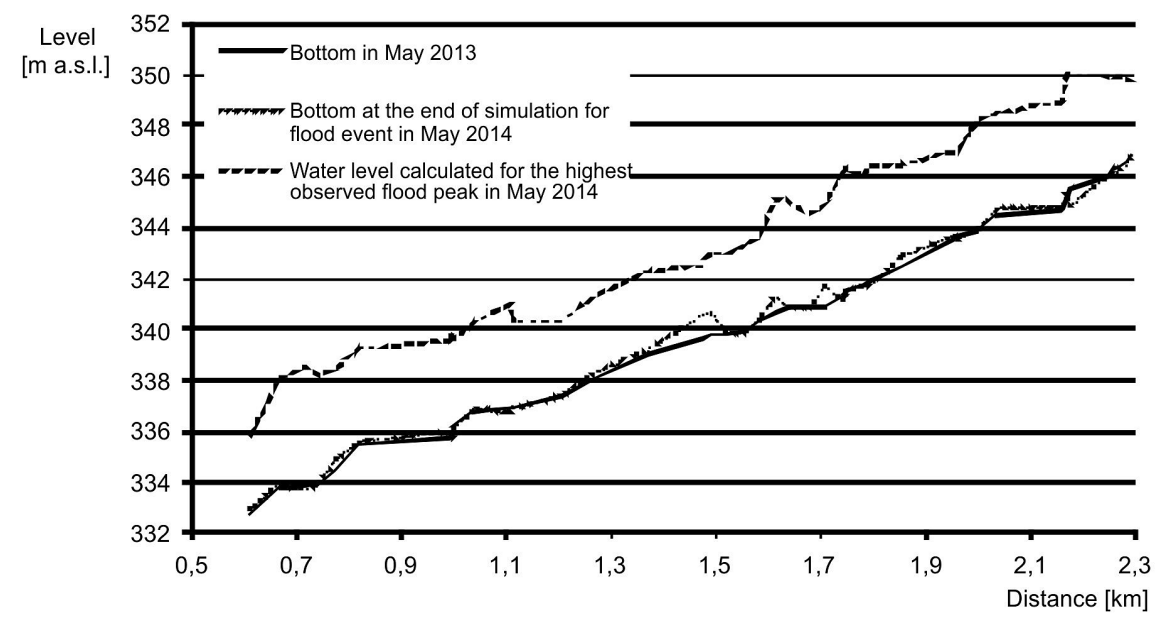

Figure 6. Numerical simulation of stream channel evolution after flood event in 2014 


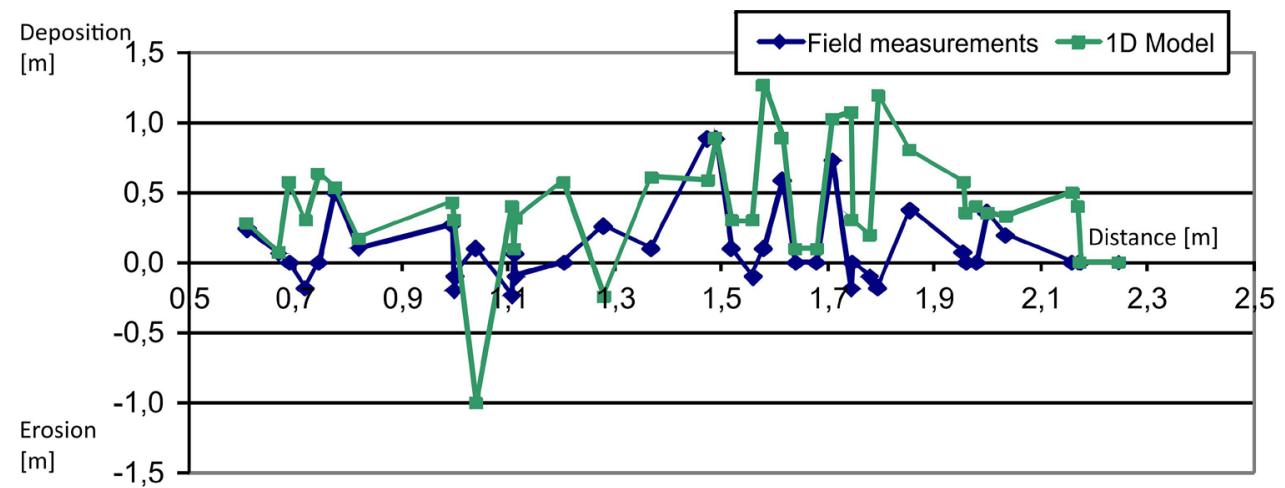

Figure 7. Bottom level changes at the studied Krzczonówka stream course after flood event in 2014

culations, are plotted on a graph (Fig. 7), including the magnitude of erosion and accumulation of material at cross sections in the Krzczonówka Stream channel, both values measured in the field and the values calculated based on the studied model. Clear differences in the obtained values can be noticed on the graph. However, what is very important, is that the identified erosional and accumulation tendencies are the same at corresponding cross sections: measured values and values calculated based on the model. This also provides a practical form of model validation. The discrepancies between values may result from underestimating Strickler's coefficients or may be due to an inaccurate specification of active channel width in the model. An active channel width may assume slightly different values in the special case when large masses of bed load are transported during a flood event.

\section{CONCLUSIONS}

1. The intensity of processes, which occurred in the channel reaches upstream and downstream from the check dam being modified, was caused by two simultaneously occurring events: (1) river engineering works already started to lower the dam, and (2) extremely high flows caused by sudden and heavy rainfall. It was possible to develop a numerical model for the stream channel section located downstream of the dam, which satisfactorily represents the progress of channel processes as they occurred during the studied flood event.

2. The field measurements in the channel of Krzczonówka Stream carried out after a flood event revealed that great changes had occurred in the stream channel. Some stream channel reaches became covered with a thick layer of sediment. At the same time, the number of erosion-produced side cuts increased, while the number of knickpoints and rock outcrops decreased. Deposition is currently the primary process shaping the stream channel. The analyzed stream channel was filled in with material released from the sedimentation reservoir of the check dam completely. Moreover, it was additionally filled by the material from the right bank, where strong lateral erosion had occurred. Substantial erosion, due to a flood event, in the stream channel section located upstream of the check dam was observed. The material deposited up to that time within the dam reservoir and above it became eroded and transported to the channel reach downstream of the dam. Analyzing the changes in the cross-sectional area in years 2013-2016, it can be clearly noticed that the cross-sectional areas drastic decreased over the whole section below the check dam in 2013-2014. In subsequent years, the cross-sectional areas were increased due to the sediment movement, especially in the lower stream course. It is very important to note that the identified erosional and accumulation tendencies calculated for 2014 year are the same at corresponding cross sections: the measured values and the values calculated based on the model. This also provides a practical form of model validation.

3. The water level throughout the analyzed stream reach is varied. It can be caused by the sediment which was deposited at the site in large quantities most likely due to the si- 
multaneous occurrence of two factors: (1) decrease in the longitudinal slope of the channel, and (2) loss of flow velocity across the riffle, which led to a decrease in the carrying capacity of the water flow.

\section{REFERENCES}

1. Bagnold R.A. 1966. An approach to the sediment transport problem from general physics., U.S. Geological Survey Professional Paper 422, 231-291.

2. EFD - 23 October 2000. http://tarliskagornejraby.pl

3. Hubicki S. Zabudowa potoków górskich (Mountain streams engineering), Nakł. Koła St. Inż. Las, Lwów, Politechnika 1927, część I, II, III, 5-172 (in Polish).

4. Jeleński J., Wyżga B. 2016. Możliwe techniczne i biologiczne interwencje w utrzymaniu rzek górskich, Stowarzyszenie Ab-Ovo, Kraków, 7-83.

5. Kaszowski L., Krzemień K. 1977. Structure of mountain channel systems as examplified by chosen Carpathian streams. Studia Geomorph. Carpatho-Balcan. 11, 111-125.

6. Klimek K. 1987. Man's impact on fluvial processes in the Polish Western Carpathians. Geogr. Annaler 69 A, 221-226.

7. Korpak J. 2007. The influence of river training on mountain channel changes (Polish Carpathian Mountains). Geomorphology 92, 166-181.

8. Korpak J., Krzemień K., Radecki-Pawlik A. 2008. Influence of anthropogenic factors on chan ges of Carpathian stream channels. Monografia PAN, Oddział w Krakowie, 7-89 (in Polish).

9. Krishnappan, B.G. 1981. Unsteady, nonuniform, mobile boundary flow model - MOBED., Hydraulics Division, National Water Research Institute Burlington, Ontario, 1-100.

10. Lenar-Matyas A., Korpak J., Mączałowski A.,
Wolański K. 2015. Zmiany w przekrojach poprzecznych potoku Krzczonówka po przejściu fali powodziowej, Infrastruktura i Ekologia Terenów Wiejskich, PAN Oddział w Krakowie, nr 4, 965-977 (in Polish).

11. Łapuszek M. 2013. The establish and prediction of the river channel evolution of the left-side tributaries of the upper Vistula River. Monografia 446, Politechnika Krakowska, Kraków, 7-178 (in Polish).

12. Łapuszek M., Paquier A. 2007. Practical Application of 1-D Sediment Transport Model, Archives of Hydro-Engineering and Environmental Mechanics, 54(4), 183-198.

13. Meyer-Peter, E., Müller, R. 1948. Formulas for bed-load transport. Report on second meeting of IARH. IAHR, Stockholm, 39-64.

14. Park I., Jain S.C. 1987. Numerical simulation of degradation of alluvial channel beds. J. of Hydr. Eng., ASCE 113 No. 7 July, 845-850.

15. Paquier, A. 2003. What are the problems to be solved by a $1-\mathrm{D}$ river sediment transport model? Example of RubarBE software. Selected Problems of Water Engineering, Politechnika Krakowska Cemagref - results of cooperation, 9-11 October 2003, seminary, Cemagref Editions 2004, BP 44, 92163 Antony, France, 75-85.

16. Project No. 46/43/1473.

17. Rahuel J.L., Holly F.M., Chollet J.P., Belleudy P. J., Yang G. 1989. Modeling of river-bed evolution for be-load sediment mixture. J. of Hydr. Eng., ASCE 115 No. 11 Nov, 1521-1542.

18. Ratomski J. 1991. Bed-load material sedimentation in check dams of Flysch Carpathians. Politechnika Krakowska, Kraków, 123, 1-131 (in Polish).

19. Sobieszczyk P. 2017. Migrationbarriers removal in the Wisłoka River catchment area and partial restoration of gravel habitats for lithophilous fish along the Wisłoka River reach from the weir in Mokrzec to Pustków. Przegląd Przyrodniczy, XXVIII, 4, 170-192 (in Polish). 